\title{
Policy Directions for Social Control of Street Crimes in Padang City - Indonesia
}

\author{
Erianjoni, Dedi Hermon
}

\begin{abstract}
The problem of Street crimes has become an urgent problem in Padang City in the last 2 years, it was recorded that in 2019 there were 1116 cases and 31 cases during January 2020. referring to this data that Padang City, West Sumatra Province is an unsafe city for its citizens both during the day and at night. In reality, a solution is needed to suppress these crimes through a system or appropriate preventive social control mechanism, so that it does not rely on police actions that tend to be coercive or repressive, so that it will not solve the problem. This research was conducted with qualitative research with the type of case studies in Padang City, data collection using questionnaires, in-depth interviews, observation, and documentation study, data were analyzed using interactive analysis models, also using the Integrated System Model (ISM). The research results showed that the form of Street crimes was carried out individually and in groups, the causes of Street crimes occurred due to internal and external factors, and the policy of Street crimes social control policies, i.e the making of policies and regulations, then the effectiveness of social control, increased public participation, consistency in law enforcement, and social education for unemployed youth has become a more important policy than any other policy.
\end{abstract}

Keywords: street crimes, social control, policy direction, padang city.

\section{INTRODUCTION}

Criminal acts, whether they are crimes or violations, are basically attached to the dynamic conditions of people's lives who have a very complex background, which includes socio-cultural aspects as well as ideological, political aspects as well as the ability and effectiveness of state apparatus and society [1]. According to [2] empirical study, crimes committed by the lower classes (Street crimes) occur due to economic pressure from lower-class society, and because of the process of alienation which loosens social ties among its members. This is consistent with empirical research conducted by $[3,4]$ who found that there were deviations in the behavior of community members due to changes in structure and values as well as economic inequality.

One of the crimes that must be the priority of the Police of the Republic of Indonesia (POLRI) to create a sense of security in society is thuggery and Street crimes $[5,6]$. The

Manuscript received on February 18, 2021.

Revised Manuscript received on March 30, 2021.

Manuscript published on March 30, 2021.

* Correspondence Author

Dr. Erianjoni, M.Si*, Asosiasi profesor of sociologi education in Universitas Negeri Padang. Email: erianjonisosiologi@gmail.com

Prof. Dr. Dedi Hermon, Profesor of disaster geography in Universitas Negeri Padang. Email: dihermon006@gmail.com

(C) The Authors. Published by Blue Eyes Intelligence Engineering and Sciences Publication (BEIESP). This is an open access article under the CC BY-NC-ND license (http://creativecommons.org/licenses/by-nc-nd/4.0/)
Published By:

Blue Eyes Intelligence Engineering

and Sciences Publication

(C) Copyright: All rights reserved.

POLRI leadership has determined the prevention of these two types of crimes as a priority program with the consideration that these crimes have a very broad impact on society, especially from a psychological aspect apart from the impact of the economic losses suffered by victims. For victims and other communities, this crime had a profound impact on the emergence of a very deep sense of fear, so that people's sense of security would be lost if the POLRI did not take countermeasures. This will have an impact on the fluctuation of public trust in POLRI.

Basically, thuggery and Street crimes are the iceberg phenomena of crime caused by several factors that appear on the surface [7]. Therefore, tackling thuggery and street crimes cannot only be done by repressive measures against the perpetrators. However, it must be comprehensively resolved by solving the root of the problem or often referred to as solving problems from the upstream.

Research of $[2,8]$ explains that Street crimes is a social problem that is still difficult to overcome in developing countries, such as Indonesia. The problems of poverty, ignorance, and the large number of unemployed people that continue to crowd the corners of the homeland have contributed to the rampant crimes of various crimes that have occurred in society. Street crimes are mostly committed by people from the lower classes who have low educational and economic levels, where the main problem in this crime is related to stomach problems. Crimes committed by the lower classes (street crimes) occur because of economic pressure from the lower classes of society, and because of a process of alienation that loosens social ties among its members. Access or opportunity to act criminally varies based on social class, grassroots groups are rarely involved in organized crime or corporate crime; they are mostly involved in conventional/Street crimes (pickpocketing, robber, theft, etc).

Padang City as a city that is classified as metropolitan is also faced with the problem of Street crimes [9]. In January 2020, there were 31 cases of Street crimes and 52 suspects in Padang City, both of which were committed individually or in groups. Meanwhile, if we compare it to the data in 2019, there were 1115 criminal cases that occurred in the city of Padang. In terms of time, Street crimes do not only occur at night, they also occur during the day. Then followed by four other cases, namely theft with a weighting of 896 cases, 233 cases of drugs, 190 cases of fraud, and 172 cases of violent theft [10-12]

In the context of social control of Street crimes carried out in a coercive or preventive manner, according to the Head of Police the Padang City, perpetrators of Street crimes who are disturbing the public will be shot on the spot.

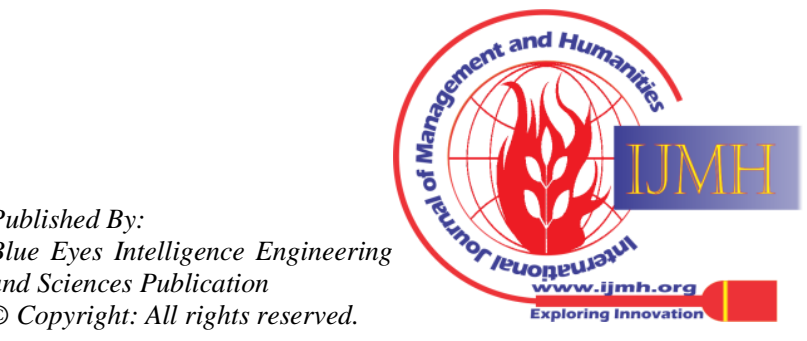




\section{Policy Directions for Social Control of Street Crimes in Padang City - Indonesia}

For these perpetrators, decisive and measured action will be taken in the form of shooting on the spot, especially those who are recidivists. This firm action targets every criminal who often disturbs the public, including motor vehicle theft, mugging, robbery, and violent theft. Supervision will be carried out by the Criminal Investigation Unit (CIU Police) by spreading members to locations that are considered vulnerable. "Especially in crowded places such as markets and others" [11].

The efforts made by the police still appear to be coercive in nature and will only reduce the impact temporarily, but the problems upstream of these problems have never been seen, such as problems in the family, unemployment, weak supervision by the authorities due to the limited number of personnel in the field or lack of social participation the society in preventing crime on the street. So starting from the issues and problems above, it is necessary to design an appropriate policy direction as a model of social control to overcome the increasing cases of Street crimes, through serious studies and research. This research will reveal: 1) forms of Street crimes; 2) factors causing Street crimes; 3) policy directions in social control of Street crimes problems in Padang City?.

\section{RESEARCH METHODS}

This type of research is qualitative research (with a case study type). The research location is in Padang City, a school where there is an increase in Street crimes from year to year. The research sample was determined by purposive sampling, i.e by criteria, academics (sociologists), DPRD members of Padang City, Head of Criminal Investigation Unit (CIU
Police) Padang City, Head of Satpol PP, non-formal education experts, and society leaders of Padang City. Data collection techniques with in-depth interviews (depth interview), passive participation observation and document study. To test the validity of the data, the data triangulation technique was carried out by means of triangulation of sources, methods and time [13]. Data analysis was carried out descriptively with the interactive analysis model from Miles and [14] i.e reduction, data display, and conclusion. In order to obtain a policy direction, it is used with the Integration System Model (ISM) analysis [15].

\section{FINDINGS AND DISCUSSION}

\section{A. Forms of street crimes in Padang City}

From the results of research conducted that there are forms of Street crimes that occur in the city of Padang, seen from the perspective of the perpetrators it can be grouped into 2, i.e crimes committed individually and in groups henceforth will be explained, as follows:

\subsection{Individual Crimes}

Pickpocketing: This is a type of Street crimes, in which the perpetrator takes action on public transportation, such as on the route of Pasar Raya-Lubuk Buaya, Pasar Raya-Teluk Bayur, Pasar Raya-Indarung, and so on (Fig. 1). Generally, the perpetrators do pickpocketing by pretending to be a passenger and observing them look for opportunities to take action, by approaching the victim when public transportation conditions are busy at rush hour, morning or evening, usually those targeted by young women and mothers. If they have got the results they will go down.

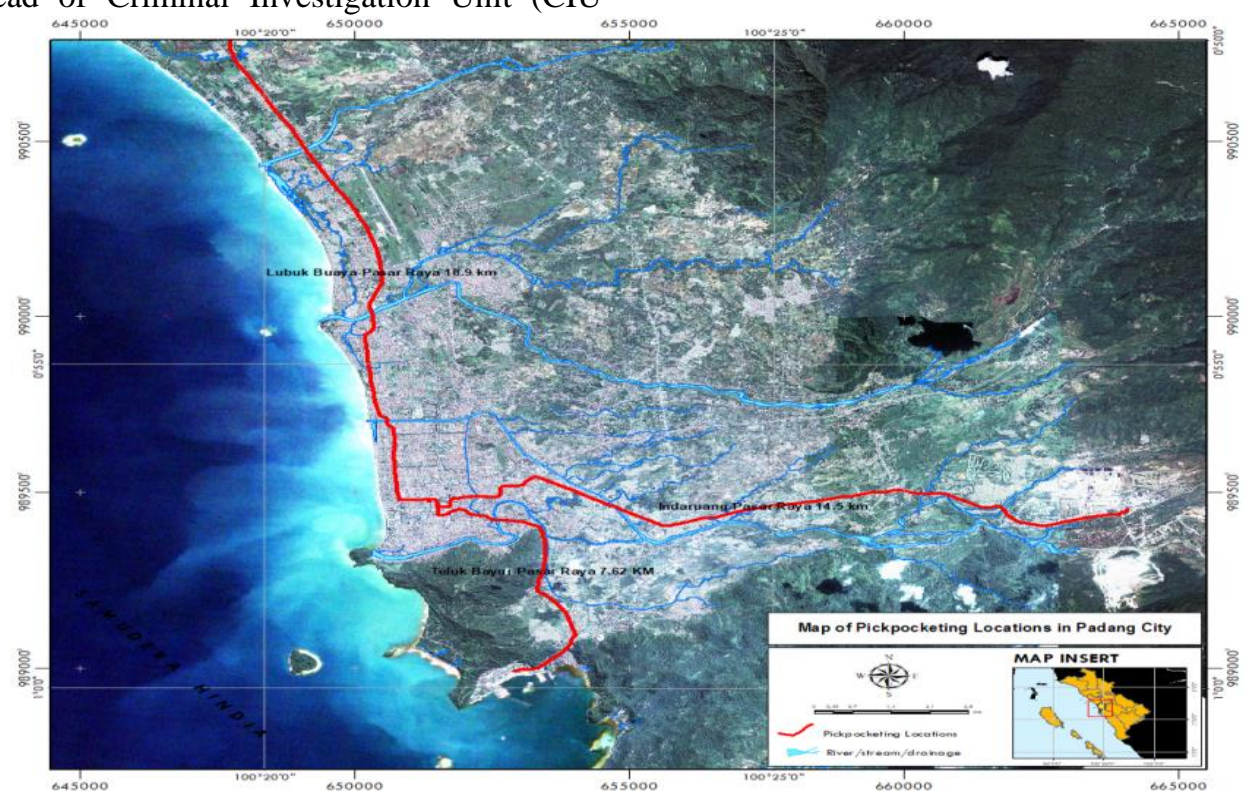

Fig 1. Route information map of pickpocket crimes in Padang City.

Thieves: This criminal behavior occurs on public transportation such as city transportation and also when koban is in certain places that are rather quiet. In public transportation, threatening or pointing a sharp weapon at victims who are considered to have the potential to threaten them, for example, are small, somewhat feminine, seem to have money seen from the status or ownership symbol.

Illegal levies: The target of this crime is drivers of public transportation. Along the way, city transport drivers have to pay a sum of money, on average Rp.2000-Rp.5000,-. The perpetrators generally carried out their actions at road intersections and at public transportation car stops in front of the Muhammadiyah Mosque, street of Muhammad Yamin, street of Gadjah Mada, street of Labor Air Tawar, and in the Rawang Mato Air area (Fig. 2).

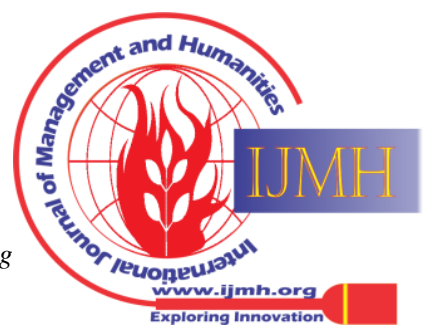




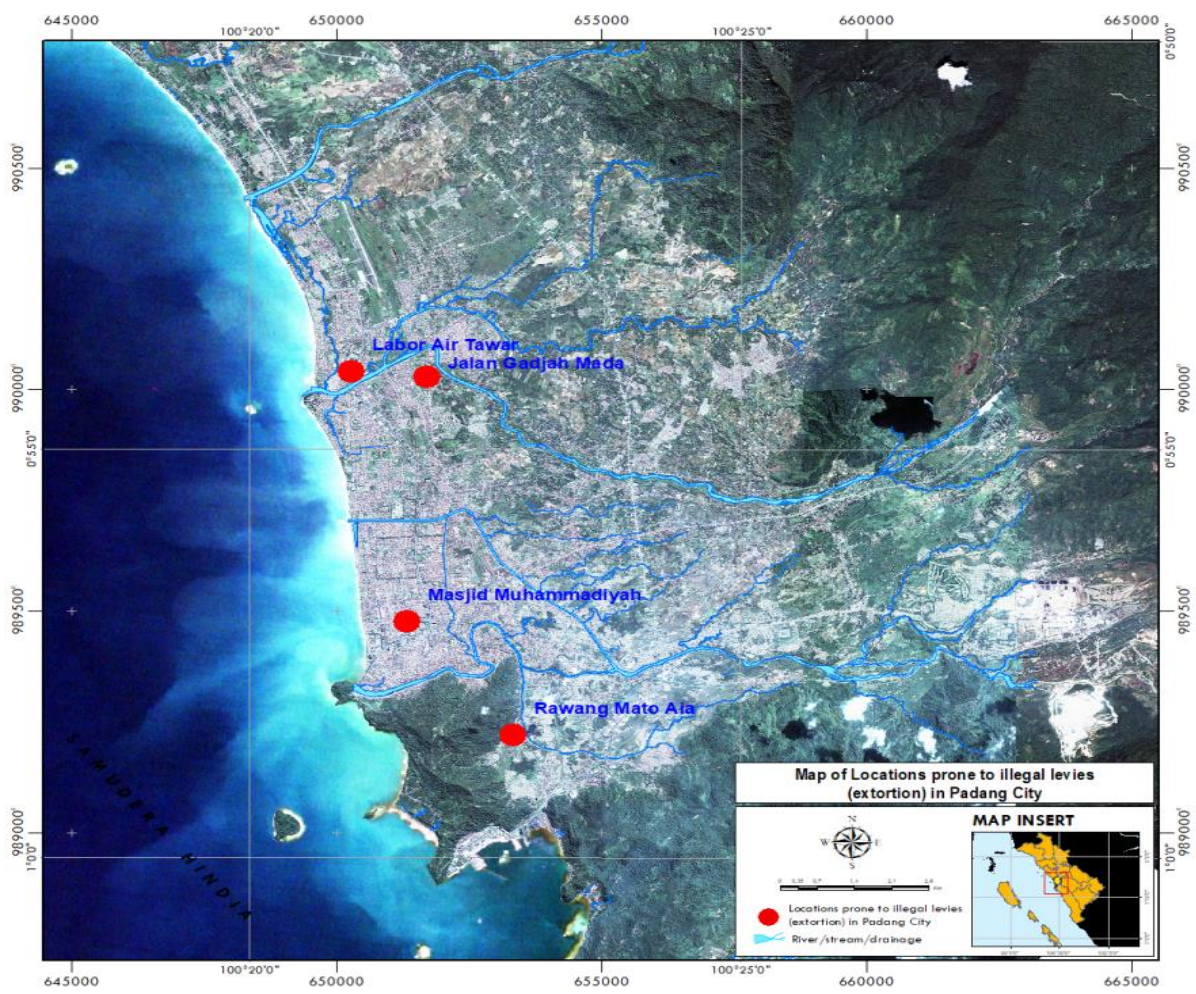

Fig 2. Information on general location map of illegal levies in Padang City.

\subsection{Group Crimes}

Mugging: This is a type of crime that often occurs in Padang City. Thief action is generally carried out in groups using motorbikes. In the action, one person is the driver and one person is the mugging.

Robber: The phenomenon of rubber-type crime has been around for a long time in Padang City, and sometimes recurs.
These crimes were generally committed by groups at night at 23 - 00 WIB when the police were off guard. They operate at certain points, such as in the street of by Pass area, especially in the border area between Padang City and Padang Pariaman Regency, street of Adinegoro Lubuk Buaya, along the street of Muaro Padang, street of Dr. Sutomo Marapalam, or street of Cengkeh Lubuk Begalung Padang (Fig. 3).

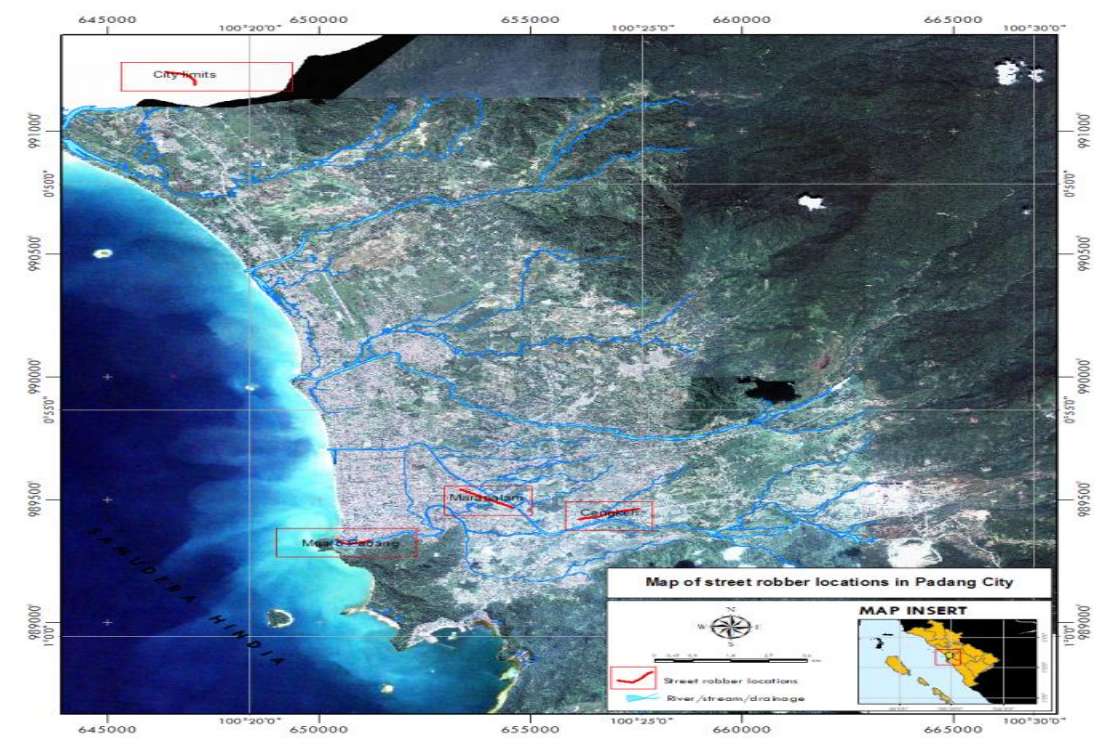

Fig 3. Route information map of robber crimes in Padang City.

\section{B. Factors causing street crimes in Padang City}

Broadly speaking, this research reveals the factors that cause Street crimes in Padang City, i.e:

Internal factors: is a factor that comes from aspects within the perpetrator itself $[16,17]$ i.e 1$)$ unhealthy mental attitude, there is no shame and fear of the perpetrators causing them to continue to be involved in crime, even they are classified as recidivists; 2) An outlet for disappointment. Disappointment with parents, siblings, female friends, or social structures, is vented through a crime with friends who are the same or have the same level of disappointment; 3) Desire to be praised. Feelings of wanting to be praised or to show identity or group identity have an impact by being turned into crime as a medium to make this happen; and 4)

Published By:

Blue Eyes Intelligence Engineering

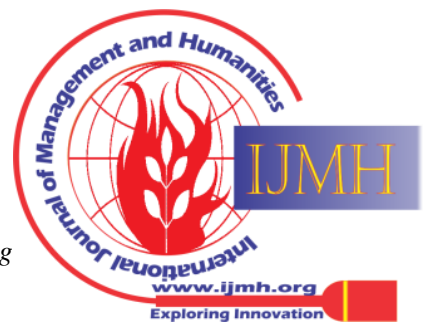


Inability to absorb norms; The problem of a person's difficulty in absorbing internalized norms through school education and religious education and family education.

External factors: i.e factors that originate from outside the perpetrator of the crimes, i.e social structure and process factors [16, 17], including those found in this research, i.e 1) Disharmonization of families: Most of the perpetrators have problems in family backgrounds, such as divorce, domestic violence, and extramarital affairs; 2) Encouragement of economic needs; Crimes for economic fulfillment such as pickpockets, bullying, and thieves, are generally triggered by classic factors for survival; 3) The influence of the environment and mass media: Unhealthy environmental factors, which are indicated by an unhealthy group of friends, and reinforced by the media that provide less knowledge and education than the unhealthy views and demands of the mass

\begin{tabular}{|c|c|c|c|c|c|c|c|c|c|}
\hline \multicolumn{2}{|c|}{ Expert List } & \multicolumn{8}{|c|}{ it Element List } \\
\hline No & \multicolumn{4}{|c|}{ Element Description } & & & & & \\
\hline 1 & \multicolumn{4}{|c|}{ Determination of Making Social Mappi... } & & & & & \\
\hline 2 & \multicolumn{4}{|c|}{ Effectiveness of social control } & & & & & \\
\hline 3 & \multicolumn{4}{|c|}{ Increased public participation } & & & & & \\
\hline 4 & \multicolumn{4}{|c|}{ Cross-sectoral cooperation in law enfo... } & & & & & \\
\hline 5 & \multicolumn{4}{|c|}{ Policy and regulation making } & & & & & \\
\hline 6 & \multicolumn{4}{|c|}{ Consistency in law enforcement } & & & & & \\
\hline 7 & \multicolumn{5}{|c|}{ Social education for unemployed youth } & & & & \\
\hline SSIM & \multicolumn{3}{|c|}{ Reachibility Matrix } & \multicolumn{2}{|c|}{ Revision Matrix } & \multicolumn{2}{|c|}{ Final Matrix } & Graph & Structure \\
\hline NO & A1 & $A 2$ & A3 & A4 & A5 & A6 & A7 & & \\
\hline A1 & 1 & 1 & 1 & 1 & 1 & 1 & 1 & & \\
\hline A2 & 0 & 1 & 1 & 1 & 1 & 1 & 1 & & \\
\hline A3 & 0 & 1 & 1 & 1 & 1 & 1 & 1 & & \\
\hline A4 & 0 & 1 & 1 & 1 & 1 & 1 & 1 & & \\
\hline $\mathrm{A} 5$ & 0 & 1 & 1 & 0 & 1 & 1 & 1 & & \\
\hline A6 & 0 & 1 & 1 & 1 & 1 & 1 & 1 & & \\
\hline A7 & 0 & 1 & 1 & 1 & 1 & 1 & 1 & & \\
\hline
\end{tabular}

media; 4) The process of socializing deviant subcultural values. The occurrence of socialization in the form of deviant subcultural values, usually in the crime group, will encourage someone to engage in anti-social behavior; and 5) There are different social ties. This is related to the presence of values in a unique group that is passed on to its members because these values are a group ideology that must be preserved or instilled.

\section{Direction of social control policies on Street crimes problems in Padang City}

From the results of the ISM analysis with the experts, it is illustrated how the formulation of the direction of social control policies on the Street crimes problem in Padang City, as in Fig 4 below.

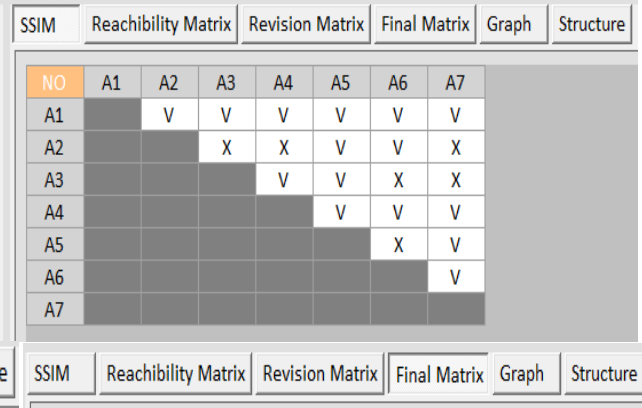

\begin{tabular}{|c|c|c|c|c|c|c|c|c|c|}
\hline \hline N0 & $A 1$ & $A 2$ & $A 3$ & $A 4$ & $A 5$ & $A 6$ & $A 7$ & $D P$ & $R$ \\
\hline$A 1$ & 1 & 1 & 1 & 1 & 1 & 1 & 1 & 7 & 1 \\
\hline$A 2$ & 0 & 1 & 1 & 1 & 1 & 1 & 1 & 6 & 2 \\
\hline$A 3$ & 0 & 1 & 1 & 1 & 1 & 1 & 1 & 6 & 2 \\
\hline$A 4$ & 0 & 1 & 1 & 1 & 1 & 1 & 1 & 6 & 2 \\
\hline A5 & 0 & 1 & 1 & 0 & 1 & 1 & 1 & 5 & 3 \\
\hline A6 & 0 & 1 & 1 & 1 & 1 & 1 & 1 & 6 & 2 \\
\hline A7 & 0 & 1 & 1 & 1 & 1 & 1 & 1 & 6 & 2 \\
\hline$D$ & 1 & 7 & 7 & 6 & 7 & 7 & 7 & & \\
\hline L & 3 & 1 & 1 & 2 & 1 & 1 & 1 & & \\
\hline
\end{tabular}

Fig 4. Element Description, Structural Self Interaction Matrix (SSIM), and Final Reachibility Matrix (RM)

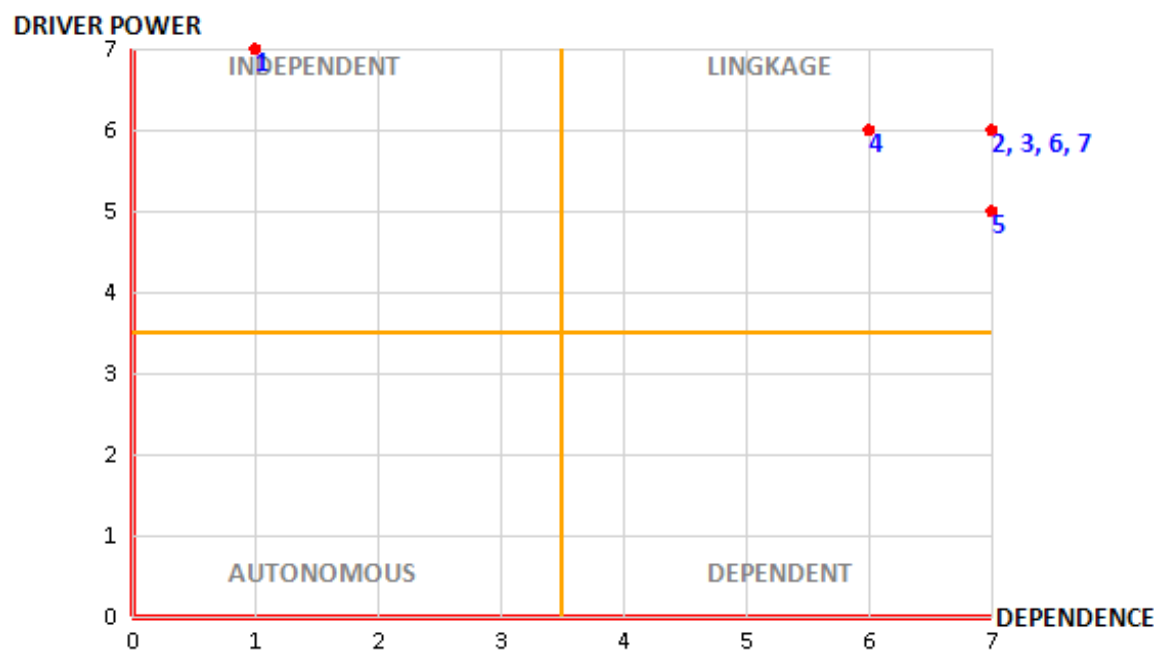

Fig 5. Analysis of the Atrice Impacts Croises-Multiplication Appliqué a Classement (MICMAC) social control strategy on the problem of Street crimes in Padang City.

On Fig. 4 and 5 above the important policies carried out by the government in the social control strategy of Street crimes in Padang City, i.e the making of policies and regulations, then the effectiveness of social control, increasing public participation, consistency in law enforcement, and social education for unemployed youth become a policy that is more important than other policies.

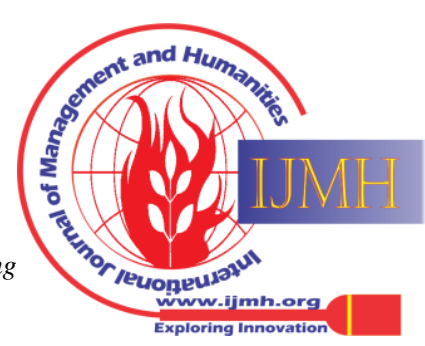




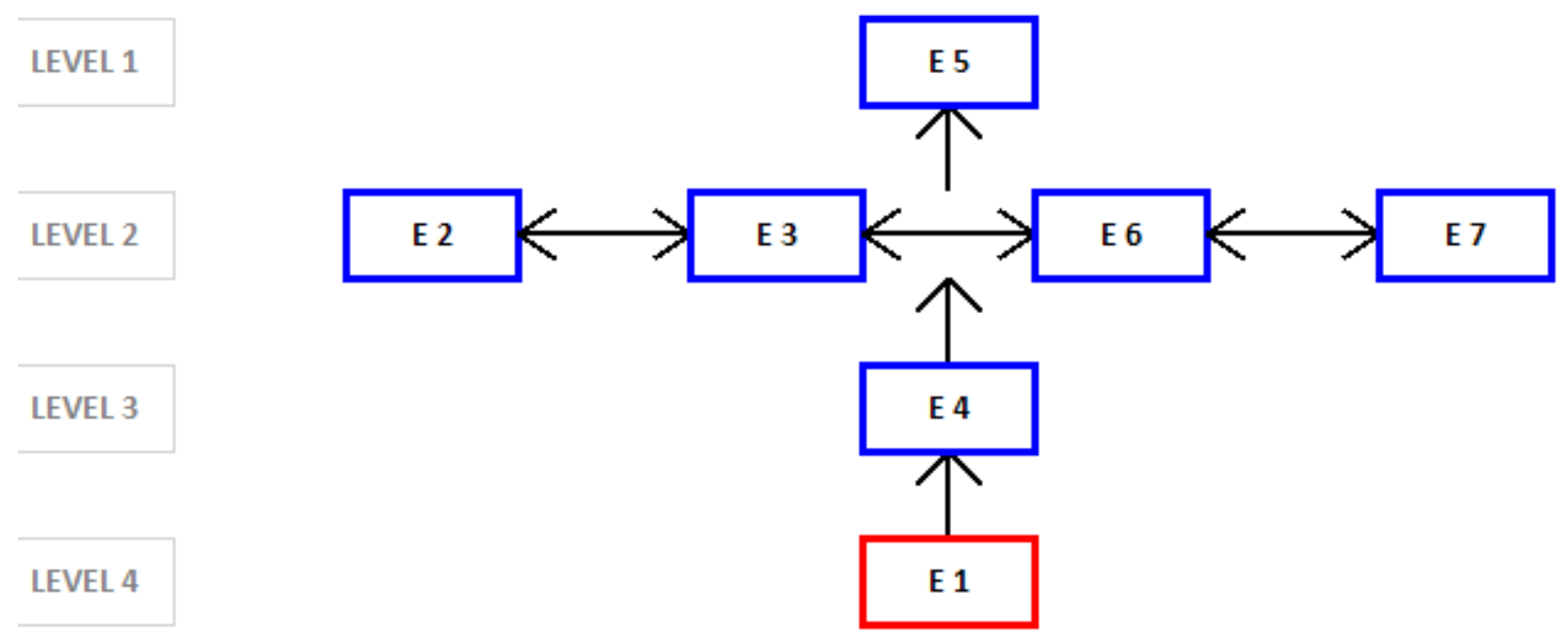

Fig 6. Level of strategy for developing social control over Street crimes in Padang City

Advances in technology, especially the mass media, also influence someone to do bad things, such as Street crimes in Padang City. The mass media provide stimulation to a person's thoughts in social life. In fact, it is not uncommon for television shows to provide examples of committing motor vehicle theft, although basically, these shows do not intend to provide an example. The thinking and perceptive power of each individual must also be different, therefore, television shows can give a bad impression to someone. One of the theories in socio-criminology is the "Differential Association" theory which is based on the learning process, namely that criminal behavior is learned behavior. According to $[18,19]$, when criminal behavior is studied, what is learned includes 1) techniques for committing crimes; 2) certain motives, encouragement, justification reasons, and attitudes [3]. This view is inversely proportional to the results of research, where one of the causes of imitation is due to the imitation of robbery crimes in other areas by thugs in Padang, City including the role of the mass media which reports on various modes of Street crimes without the presence of sources from the police who explain them in a balanced way. Furthermore, it also describes the factors that influence the occurrence of Street crimes from a victimology perspective, namely the science of victims, where one of the studies is to find the causes of victimization. Based on the results of the study, there are 3 main factors that influence the occurrence of Street crimes from the perspective of Victimology [5, 19, 20].

Repressive measures are a conceptual effort to tackle crime after a crime has occurred [21]. Countermeasures with repressive measures are intended to take action against the perpetrators of crimes according to their actions and to repair them again so that they are aware that the actions they have committed are illegal and detrimental to society, so they will not repeat them and other people will also not do them considering the very heavy sanctions they will bear.

\section{CONCLUSION}

Street crimes cases in Padang city have increased from year to year, causing social unrest for the community. Various efforts have been made by stakeholders to minimize the crime rate, but the results have not been optimal. The research offers policy direction to tackle Street crimes in

Padang City by collaborating with the involvement of various related parties. These policies include making policies and regulations, then the effectiveness of social control, increasing public participation, consistency in law enforcement, and social education for unemployed youth which are more important policies than other policies.

\section{ACKNOWLEDGMENT}

This research was supported by the Institute for Research and Community Service (LP2M) Universitas Negeri Padang (UNP) on Street crimes in Padang City. We also thank Rector UNP, LP2M UNP Staff, Students involved in research, and Padang City Police for their support in this research.

\section{REFERENCES}

M A. Syahrin. The Immigration Crime and Policy: Implementation of PPNS Authorities on Investigation. JILS, 3, 2018. 175.

2. M. Mappa, F. Tola, Suardi. Begal motor sebagai perilaku menyimpang Jurnal Equilibrium Pendidikan Sosiologi, 4(1), 2016. 1-10.

3. Syani, A. Sosiologi Kriminalitas. Bandung: Remaja Karya. 1987.

4. W. Anjari. Fenomena Kekerasan Sebagai Bentuk Kejahatan (Violence). E-Journal Widya Yustisia, 1(1), 2014. 42-51.

5. B. Waluyo. Viktimologi (Perlindungan Saksi dan Korban). Jakarta: Sinar Grafika. 2011

Erianjoni. Pengamat: Aksi Kejahatan Jalanan Hanya untuk Eksistensi. atan-jalanan-di-padang-hanya-untuk-eksistensi, accessed January 18 , 2020. 2020 Mengkonsumsi Minuman Keras di Desa Bongo IV Kecamatan Paguyaman Kabupaten Boalemo. Jurnal Pascasarjana, 2(2), 2018

8. H.D. Purnomo. Peran Tim Anti Bandit Satreskrim Polrestabes Surabaya dalam penanggulangan tindak pidana kejahatan jalanan. Jurnal Sosiologi Dialektika, 14(1), 2019. 34-43

9. Erianjoni., Ikhwan. Pola dan Jaringan Prostitusi Terselebung di Kota 112-118

10. Suharyadi, Sampara, K. Ahmad. Kejahatan Dunia Maya (Cyber Crime) Dalam Prespektif Hukum Islam. Journal of Lex Generalis (JLG), 1(5), 2020. 761-773.

11. Erianjoni. Sosiolog : Kejahatan Jalanan di Padang Akan Terus Ada https://rri.co.id/daerah/786368/sosiolog-kejahatan-jalanan-di-padang-ak an-terus-ada, accessed January 18, 2020. 2020 b

Erianjoni. Sosiolog Sebut Bandit Jalanan Padang Ingin Diakui. accessed January 18, $2020.2020^{c}$

18 ,
sebut-ba

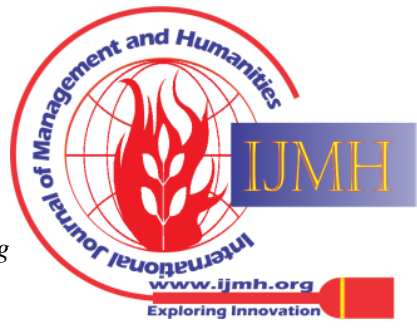


13. D. S Triangulation. The use of triangulation in qualitative research. In Oncology nursing forum. 41(5), 2014. 545

14. Miles M B., and Huberman A M. Analisis Data Kualitatif. Terjemahan oleh Tjetjep Rohendi Rohidi. 1992. Jakarta : Penerbit Universitas Indonesia

15. A. Rusydiana. Aplikasi Interpretive structural modeling untuk strategi pengembangan wakaf tunai di Indonesia. JEBIS (Jurnal Ekonomi dan Bisnis Islam), 4(1), 2018. 1-17

16. B. Waluyo. Viktimologi (Perlindungan Saksi dan Korban). Jakarta: Sinar Grafika. 2011

17. R. Gunawan, M,H Mahendra, H. R Zakaria, M. Qoyu. Behavior Motives and Legal Study of Commercial Sex Workers Around Pemalang District Terminal Area. Law Research Review Quarterly, 6(1), 2020. 53-68.

18. J.H Laub, R.J Sampson. The Sutherland-Glueck debate: On the sociology of criminological knowledge. American Journal of Sociology, 96(6), 1991. 1402-1440.

19. E.H Sutherland, D.R Cressey. A Sociological Theory of Criminal Behaviour. Harper \& Row. 1969

20. F.A. Haiti. Peran anggota Satuan Reserse Kriminal dalam menanggulangi kejahatan jalanan. Jurnal Sosiologi Dialektika, 13(2), 2018. 141-151.

21. Arief B N (2001) Masalah Penegakan Hukum dan Kebijakan Penanggulangan Kejahatan. Bandung: PT. Citra Aditya Bakti.

\section{AUTHORS PROFILE}

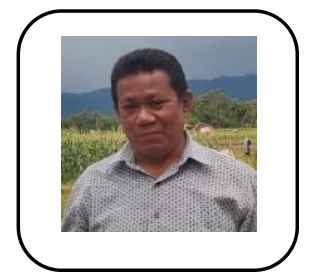

Dr. Erianjoni, M,Si is a asosiasi profesor of sociologi education, and senior lecturer of social sciences in Universitas Negeri Padang Indonesia

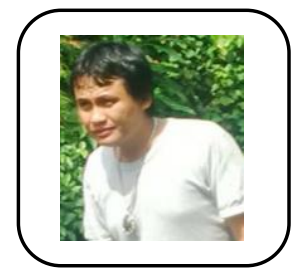

Prof. Dr. Dedi Hermon, MP is a profesor of disaster geography, and senior lecturer of environmental sciences in Universitas Negeri Padang - Indonesia

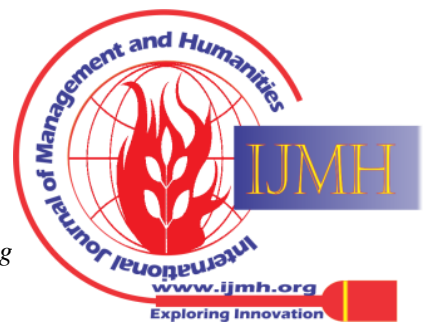

